\title{
Spatio-temporal heterogeneity of riparian soil morphology in a restored floodplain
}

\author{
B. Fournier ${ }^{1,2,3, *}$, C. Guenat ${ }^{2,3, *}$, G. Bullinger-Weber ${ }^{4}$, and E. A. D. Mitchell ${ }^{1}$ \\ ${ }^{1}$ Laboratory of Soil Biology, University of Neuchâtel, Rue Emile-Argand 11, 2000 Neuchâtel, Switzerland \\ ${ }^{2}$ WSL Swiss Federal Institute for Forest, Snow and Landscape Research, Research Unit Community Ecology, Site Lausanne, \\ station 2, 1015 Lausanne, Switzerland \\ ${ }^{3}$ Ecole Polytechnique Fédérale de Lausanne (EPFL), School of Architecture, Civil and Environmental Engineering (ENAC), \\ Laboratory of Ecological Systems (ECOS), station 2, 1015 Lausanne, Switzerland \\ ${ }^{4}$ Biogeosciences Laboratory, Institute of Geology and Paleontology, University of Lausanne, 1015 Lausanne, Switzerland \\ *These two authors contributed equally to this paper.
}

Correspondence to: B. Fournier (bertrand.fournier@unine.ch)

Received: 28 January 2013 - Published in Hydrol. Earth Syst. Sci. Discuss.: 5 April 2013

Revised: 12 August 2013 - Accepted: 3 September 2013 - Published: 17 October 2013

\begin{abstract}
Floodplains have been intensively altered in industrialized countries, but are now increasingly being restored. It is therefore important to assess the effect of these restoration projects on the aquatic and terrestrial components of ecosystems. However, despite being functionally crucial components of terrestrial ecosystems, soils are generally overlooked in floodplain restoration assessments.

We studied the spatio-temporal heterogeneity of soil morphology in a restored (riverbed widening) river reach along the River Thur (Switzerland) using three criteria (soil diversity, dynamism and typicality) and their associated indicators. We hypothesized that these criteria would correctly discriminate the post-restoration changes in soil morphology, and that these changes correspond to patterns of vascular plant diversity.

Soil diversity and dynamism increased $5 \mathrm{yr}$ after the restoration, but some typical soils of braided rivers were still missing. Soil typicality and dynamism were correlated to vegetation changes. These results suggest a limited success of the project, in agreement with evaluations carried out at the same site using other, more resource-demanding, methods (e.g., soil fauna, fish diversity, ecosystem functioning).

Soil morphology provides structural and functional information on floodplain ecosystems. The spatio-temporal heterogeneity of soil morphology represents a cost-efficient ecological indicator that could easily be integrated into
\end{abstract}

rapid assessment protocols of floodplain and river restoration projects.

The follow-up assessment after several major floods ( $\geq$ HQ20) should take place to allow for testing the longerterm validity of our conclusion for the River Thur site. More generally, it would be useful to apply the soil morphology indicator approach in different settings to test its broader applicability.

\section{Introduction}

Floodplains fulfil ecological, economic and social functions such as biodiversity reservoirs, supply of natural resources, and flood regulation (Malmqvist and Rundle, 2002) and are increasingly appreciated for their aesthetic value and for recreational uses (Nassauer et al., 2001). However, floodplains are also one of the most threatened ecosystems worldwide (Malmqvist and Rundle, 2002; Tockner and Stanford, 2002).

In the last decades, the primary goal of floodplain management has shifted from controlling rivers to restoring their biodiversity, ecological quality and related functions and services (Malmqvist and Rundle, 2002; Tockner and Stanford, 2002). As a result, the number of river restoration projects aiming to increase ecosystem goods and services such as flood abatement, biodiversity and drinking 
water improvement is increasing worldwide (Nakamura et al., 2006, 2009; Palmer and Bernhardt, 2006; Palmer et al., 2005; Wohl et al., 2005). Assessing the outcome of these projects is essential for adaptive management, evaluation of project efficiency, optimization of future programs, and gaining public acceptance (Woolsey et al., 2007). However, restoration projects often lack post-restoration monitoring using standardized evaluation methods (with welldefined criteria and indicators), which would increase their cost-efficiency (Palmer et al., 2007; Sudduth et al., 2007; Bernhardt et al., 2005, 2007). This lack of monitoring is mainly due to lack of funding beyond the practical restoration project. Rapid yet informative, cost-effective monitoring tools are extremely sought-after; existing methods consider hydrology, physical and biological structures, and the landscape context (Rohde et al., 2004; Woolsey et al., 2007), but only include general elements with respect to soils.

Soils play a central role in critical ecosystem processes (e.g., decomposition, and water filtering), and are among the main drivers of community assembly (Gobat, 2010; Wardle, 2002). For example, soil conditions strongly determine vegetation dynamics (Caylor et al., 2005) and plant productivity and diversity (Naiman et al., 2005). In turn, the vegetation influences soil properties such as organic matter content (Quideau et al., 2001). Through their morphology, soils also provide information on ecosystem structure, and record past and present fluvial dynamics (Gerrard, 1992; Daniels, 2003; Bullinger-Weber and Gobat, 2006). This information may be especially useful when a site has been ditched, drained, and stripped of its vegetation (Cole and Kentula, 2011). Soil morphology is influenced by different factors that are related to important processes occurring in floodplain ecosystems such as erosion/sedimentation, flood dynamics, soil biota activity or pedogenesis.

Soils are not as quick to change as vegetation and hydrology, making them easier to monitor over short time intervals. In contrast to biological surveys that are dependent on species' developmental stages (e.g., vernal species, or adult stages) or population fluctuations (e.g., seasonal migration, and effects of exceptional climatic event), soil morphology can be assessed in any season and in a single field campaign. However, in order to use soils in monitoring programs it is necessary to understand how they change over space and time (Cole and Kentula, 2011). To date, most research on the impact of river restoration on floodplain soils have focused on processes such as organic matter accumulation and decomposition (Sifneos et al., 2010; Stein et al., 2009; Bush, 2008), litter decomposition (Ballantine and Schneider, 2009), or denitrification (Orr et al., 2007; Sutton-Grier et al., 2010). There is thus a need to integrate soil physical, chemical and biological factors and processes (Heneghan et al., 2008) and soil temporal dynamics (Ballantine and Schneider, 2009) into the planning and assessment of river restoration projects.

Here we explore the possible use of riparian soil morphology as indicator of floodplain dynamics by studying the spatio-temporal heterogeneity of soil morphology in a restored river reach along the River Thur (Switzerland). Our main aim was to assess the post-restoration changes in soil morphology as well as the variations of the main aspects of soil morphology along the river's lateral gradient. We considered three criteria designed to cover these main aspects: (1) soil diversity, (2) soil dynamism, and (3) soil typicality. We also investigated whether the changes in soil morphology revealed by these three criteria would reflect changes in vascular plant diversity and vegetation type. Strong correlations between vegetation and soil morphology would indicate balanced ecological processes.

\section{Methods}

\subsection{Study site}

The Thur River is a perennial river in the north-eastern part of Switzerland. Its catchment $\left(\sim 1750 \mathrm{~km}^{2}\right)$ is limestone dominated but also consists of sandstones and Pleistocene unconsolidated sediments in the lowest sections. It is the longest river in Switzerland $(\sim 127 \mathrm{~km})$ that flows continuously without any regulation by artificial reservoir or natural lakes. It is a braided river (slope $\sim 1.7 \%$ ) with a nivo-pluvial hydrologic regime characterized by flash floods. In spring and autumn, flood pulses occur as a result of snowmelt or intense precipitations. Discharge may increase dramatically within a few hours and trigger both bed load and suspended sediment transport. The mean annual discharge is $47 \mathrm{~m}^{3} \mathrm{~s}^{-1}$, with peak flows up to $1130 \mathrm{~m}^{3} \mathrm{~s}^{-1}$ and low flows down to $2.2 \mathrm{~m}^{3} \mathrm{~s}^{-1}$. Originally, the Thur River showed a clear braided morphology in its lower part. In the 1890s, the river was channelized into a $50 \mathrm{~m}$ main bed flanked, $150 \mathrm{~m}$ further, by a side channel delimited by levees. In 2002, a $1.5 \mathrm{~km}$ long section of the River Thur near Frauenfeld was restored by completely removing the right side foreland, so that the nearby alluvial forest became part of the active floodplain again.

The Thur River restoration is among the biggest river widening projects in Switzerland to date and includes postrestoration monitoring and evaluations of several stretches (Schneider et al., 2011; Schirmer, 2013; Diem et al., 2012). The present study is part of the interdisciplinary RECORD-project (http://www.cces.ethz.ch/projects/nature/ Record). We selected a study site along the Thur River near "Schäffäuli" (Fig. S1 in the Supplement). The site lies at $365 \mathrm{~m}$ a.s.l. Annual precipitation is about $1000 \mathrm{~mm} \mathrm{yr}^{-1}$ and the average annual temperature is $7.9^{\circ} \mathrm{C}$. Restoration of the site was conducted in two steps. Following a major flood in 1995, the bed protection structures were removed. In 2002 , the riverbed was widened along a $1.5 \mathrm{~km}$ stretch from 50 to $110 \mathrm{~m}$ by embankment removal and the new bank was stabilized by planting willows (Salix viminalis). This work was done with heavy equipment, thus strongly impacting floodplain soils in the restoration site. The project aimed 
to improve flood protection, to maintain drinkable water resources and to enhance the ecological quality of the riverine and riparian habitats.

We distinguished three well-differentiated situations within the study site based on field observations (topography and vegetation), available information on the site restoration, river maps and illustrations from the early 19th century, historical data on Swiss lowland braided rivers (Moor, 1958; Imboden, 1976; Gallandat et al., 1993; Baer, 1976; Roulier, 1998), and the literature on braided river soils (AFES, 2009; Guenat et al., 2003; IUSS Working Group, 2006). The first situation corresponds to open habitats with poorly developed soils closest to the river. Most restoration works were conducted in this area. Further from the river lays a riparian forest growing on deeper soils. This forest was present before restoration and restoration had only a limited impact on this area. Finally, we used an un-restored section of the same site located directly upstream from the restored one as a control that was not, or only marginally, impacted by the restoration. We expected the criteria and indicators of soil morphology presented below to show clear differences among these three areas, revealing how the restoration affected the functioning of this riparian zone.

\subsection{Data acquisition}

Soil surveys were carried out in summer 2007 along five transects corresponding to topographical surveys over time, each starting at the main riverbed and ending about $65 \mathrm{~m}$ further where no more floodplain soils were encountered. Three transects were selected in the restored area with a sampling point every $1.5 \mathrm{~m}$ in the most variable part (up to a distance of about $15 \mathrm{~m}$ from the river) and then every $3 \mathrm{~m}$ resulting in a total of 73 sampling points. Two transects were selected within the control area with a sampling point every $3 \mathrm{~m}$ resulting in 22 sampling points. The precise location, elevation and distance to the river of each sampling point were recorded.

Soils were surveyed by describing the morphology of profiles and horizons from auger borings ( $1.2 \mathrm{~m}$ length). Different variables were used to describe soil profiles and topsoils. Profile characterization was based on profile depth $(\mathrm{cm})$; number of sandy, loamy, clay, or humic horizons; total number of horizons, volumetric percentage of coarse elements $(\%)$; presence, type (reduction or oxidation), and intensity of hydromorphic features; and depth of the first horizon with hydromorphic features $(\mathrm{cm})$. Topsoil descriptions were based on horizon thickness $(\mathrm{cm})$; texture; root density; soil structure type; volumetric proportion of coarse elements and organic matter (\%); presence, type (reduction or oxidation) and intensity of hydromorphic features; macroscopic plant remains; and biological activity features.

\subsection{Soil characteristics and typology}

In order to describe changes in soil profiles and topsoils, we constructed site-specific typologies (Table 1). Two typologies (soil profile and topsoil) were generated using the complete linkage algorithm, which preserves small clusters of observations (Everitt et al., 2001) and thus prevents groups composed by few points (i.e., rare soil groups) to be included in larger groups. Cluster validity was evaluated using silhouette width - a distance-based method that assesses the quality of each cluster (Rousseeuw, 1987). Positive values indicate correct classifications and negative incorrect ones. The calculations of the indicators were based on the resulting profile and topsoil groups. To facilitate comparisons among studies, we indicated the correspondence between our typology of soil profiles and two standard soil taxonomy references (Référentiel Pédologique Français AFES, 2009; IUSS Working Group World Reference Base WRB, 2006).

\subsection{Soil criteria and indicators}

For each criterion and indicator derived from the soil typologies we defined the range of possible values, an application domain (soil profiles and/or horizons), and the rationale for its use (Table 2).

\subsubsection{Soil diversity}

Tools for measuring pedodiversity increasingly attract the attention of soil scientists (Toomanian and Esfandiarpoor, 2010; Saldaña and Ibáñez, 2004, 2007; Ibáñez et al., 1995, 1998). Information on richness, diversity and evenness of soil groups may be useful for evaluating restoration projects, especially given the high spatio-temporal heterogeneity of soils that can be observed in floodplains. The spatio-temporal heterogeneity of the soil morphology was first estimated by comparing pedodiversity indices among the forest, the open area closed to the river (restored), and the control managed pasture (un-restored) for soil profile and topsoil groups. We used three measures of alpha diversity according to Hill (1973): richness (N0), Simpson diversity (N2) and evenness $(E 2=N 2 / N 0)$. We used soil profile and topsoil groups as surrogate of species for the calculations of these metrics. As a result, $N 0$ accounts for the number of soil profile and topsoil groups, high $E 2$ indicates that all soil profile and topsoil groups are encountered with a similar frequency; and high $N 2$ reveals a large number of soil profile and topsoil groups evenly distributed.

\subsubsection{Soil dynamism}

Soil dynamism is defined here as the successions through time of sedimentation and/or erosion processes related to the fluvial regime. In natural floodplains, the fluvial dynamic creates through floods and in situ pedogenesis between flood events a high spatio-temporal heterogeneity of soil 
Table 1. Description of eight soil profile groups (1a) and seven topsoil groups (1b) resulting from a cluster analysis based on a simplified set of variables. The number of observations within each group is given in brackets. Soil taxonomy is based on AFES (2009) and correspondences to the FAO World Reference Base (WRB) for soil resources (IUSS Working Group, 2006) are given. Depth is the mean depth of a particular group of soil profiles $(\mathrm{cm})$. Texture is based on the US texture triangle (Saxton et al., 1986). For the soil profiles, texture is described using the total number of loam, sandy loam and sandy horizons within each group of soil profile, and the average number of horizons per soil profile (given below as the range of the most frequent number of horizons per soil profile to represent intra-group heterogeneity). The volumetric percentage of coarse material (blocks, pebbles and gravels) of the coarsest horizon within the soil profile is indicated under coarse material. Proportion of blocks, pebbles and gravels are given for each group in percentage of total volume. Topsoil thickness (1b) is given in $\mathrm{cm}$. Hydromorphic features represent the average depth (in $\mathrm{cm}$ ) at which hydromorphic features were first observed. The intensity of the hydromorphic features is given using a semi-quantitative scale (absence, weak, moderate, and high). The organic matter (OM) content (null $=0 \%$, low $<=10 \%$, medium $<=50 \%$, and high $>50 \%$ ) and type (no, humified, and coarse residuals) are given.

\begin{tabular}{|c|c|c|c|c|c|c|c|c|c|c|c|c|c|c|}
\hline \multirow{2}{*}{$\begin{array}{l}\text { Soil } \\
\text { profile }\end{array}$} & \multicolumn{4}{|c|}{ Taxonomy } & \multirow{2}{*}{$\begin{array}{l}\text { Depth } \\
{[\mathrm{cm}]}\end{array}$} & \multicolumn{5}{|c|}{ Number of horizons } & \multirow{2}{*}{$\begin{array}{r}\text { Coarse } \\
\text { material } \\
{[\%]}\end{array}$} & \multicolumn{3}{|c|}{ Hydromorphy } \\
\hline & \multicolumn{2}{|c|}{ AFES (2008) } & \multicolumn{2}{|c|}{ IUSS working group (2006) } & & Loam & $\begin{array}{r}\text { Sandy } \\
\text { loam }\end{array}$ & Sand & $\begin{array}{r}\text { Ave } \\
\text { per pro }\end{array}$ & $\begin{array}{l}\text { rage } \\
\text { ofile }\end{array}$ & & \multicolumn{2}{|c|}{$\begin{array}{l}\text { Hydromorphic } \\
\text { features }\end{array}$} & $\begin{array}{l}\text { Intensity of } \\
\text { hydromorphy }\end{array}$ \\
\hline $\begin{array}{l}\text { Group } 1 \\
\text { (11) }\end{array}$ & \multicolumn{2}{|c|}{$\begin{array}{l}\text { REDOXISOLS } \\
\text { fluviques } \\
\text { carbonatés }\end{array}$} & \multicolumn{2}{|l|}{$\begin{array}{l}\text { Gleyic Fluvisols } \\
\text { Calcaric }\end{array}$} & 111 & 7 & 47 & 0 & & $2-4$ & 0.3 & 15 & & Moderate \\
\hline $\begin{array}{l}\text { Group } 2 \\
(25)\end{array}$ & \multicolumn{2}{|c|}{$\begin{array}{l}\text { FLUVIOSOLS } \\
\text { typiques } \\
\text { carbonatés }\end{array}$} & $\begin{array}{l}\text { Fluvisols } \\
\text { Calcaric }\end{array}$ & & 95 & 0 & 91 & 2 & & $1-4$ & 1.2 & No & & No \\
\hline $\begin{array}{l}\text { Group } 3 \\
\text { (2) }\end{array}$ & \multicolumn{2}{|c|}{$\begin{array}{l}\text { FLUVIOSOLS } \\
\text { typiques } \\
\text { redoxiques } \\
\text { carbonatés }\end{array}$} & $\begin{array}{l}\text { Fluvisols Calcaric } \\
\text { with redoximorphic } \\
\text { features }\end{array}$ & & 120 & 1 & 10 & 0 & & 3 & 6.5 & 50 & & $\begin{array}{l}\text { Weak to } \\
\text { moderate }\end{array}$ \\
\hline $\begin{array}{l}\text { Group } 4 \\
\text { (32) }\end{array}$ & \multicolumn{2}{|c|}{$\begin{array}{l}\text { FLUVIOSOLS bruts } \\
\text { carbonatés }\end{array}$} & Regosols Calcaric & & 0.8 & 0 & 1 & 31 & & 0 & 87 & No & & No \\
\hline $\begin{array}{l}\text { Group } 5 \\
(22)\end{array}$ & \multicolumn{2}{|c|}{$\begin{array}{l}\text { FLUVIOSOLS bruts } \\
\text { carbonatés }\end{array}$} & Regosols Calcaric & & 20 & 0 & 42 & 5 & & $1-2$ & 45 & No & & No \\
\hline $\begin{array}{l}\text { Group } 6 \\
\text { (9) }\end{array}$ & \multicolumn{2}{|c|}{$\begin{array}{l}\text { FLUVIOSOLS } \\
\text { typiques } \\
\text { redoxiques } \\
\text { carbonatés }\end{array}$} & $\begin{array}{l}\text { Fluvisols Calcaric } \\
\text { with redoximorphic } \\
\text { features }\end{array}$ & & 69 & 0 & 36 & 2 & & 3 & 5.6 & 25 & & Weak \\
\hline $\begin{array}{l}\text { Group } 7 \\
(8)\end{array}$ & \multicolumn{2}{|c|}{$\begin{array}{l}\text { FLUVIOSOLS } \\
\text { typiques } \\
\text { redoxiques } \\
\text { carbonatés }\end{array}$} & $\begin{array}{l}\text { Fluvisols Calcaric } \\
\text { with redoximorphic } \\
\text { features }\end{array}$ & & 104 & 0 & 33 & 0 & & 2 & 1.1 & 50 & & $\begin{array}{l}\text { Weak to } \\
\text { moderate }\end{array}$ \\
\hline $\begin{array}{l}\text { Group } 8 \\
\text { (1) }\end{array}$ & \multicolumn{2}{|c|}{$\begin{array}{l}\text { REDUCTISOLS } \\
\text { fluviques } \\
\text { carbonatés }\end{array}$} & Gleysols Calcaric & & 30 & 0 & 2 & 0 & & 1 & 7 & 15 & & High \\
\hline \multicolumn{2}{|c|}{ Topsoil layer } & $\begin{array}{l}\text { Thickness } \\
{[\mathrm{cm}]}\end{array}$ & $\begin{array}{l}\text { Organic matter } \\
\text { content }\end{array}$ & \multicolumn{3}{|c|}{$\begin{array}{l}\text { Organic matter } \\
\text { type }\end{array}$} & $\begin{array}{l}\text { Texture (US } \\
\text { triangle) }\end{array}$ & & $\begin{array}{l}\text { locks } \\
\%]\end{array}$ & & $\begin{array}{r}\text { bbles } \\
{[\%]}\end{array}$ & $\begin{array}{r}\text { Gravel } \\
{[\%]}\end{array}$ & \multicolumn{2}{|c|}{$\begin{array}{l}\text { Hydromorphic } \\
\text { features }\end{array}$} \\
\hline \multicolumn{2}{|c|}{ Group 1 (27) } & 8 & low-medium & \multicolumn{2}{|c|}{ humified } & & Sandy loam & $n$ & & & 0 & 0 & \multicolumn{2}{|l|}{ absent } \\
\hline \multicolumn{2}{|c|}{ Group 2 (21) } & 0 & null & no & & & Sand & & .6 & & 68 & 29 & absent & \\
\hline \multicolumn{2}{|c|}{ Group 3 (10) } & 0 & null & no & & & Sand & & 1.9 & & 33 & 55 & absent & \\
\hline \multicolumn{2}{|c|}{ Group 4 (36) } & 9 & medium-low & coar & e residua & & Sandy loam & $n$ & & & 0 & 5 & absent & \\
\hline \multicolumn{2}{|c|}{ Group 5 (13) } & 9.5 & medium-low & $\begin{array}{l}\text { coar } \\
+ \text { hu }\end{array}$ & $\begin{array}{l}\text { e residua } \\
\text { mified }\end{array}$ & & Sandy loam & $n$ & & & 0 & 1 & absent & \\
\hline \multicolumn{2}{|c|}{ Group 6 (1) } & 5 & medium & hum & fied & & Sandy loam & $n$ & & & 0 & 0 & $\begin{array}{l}\text { hetero } \\
\text { iron di }\end{array}$ & $\begin{array}{l}\text { genous } \\
\text { istribution }\end{array}$ \\
\hline \multicolumn{2}{|c|}{ Group 7 (2) } & 15 & medium & coar & e residua & & Loamy sand & d & & & 0 & 1 & $\begin{array}{l}\text { related } \\
\text { spots }\end{array}$ & do roots, \\
\hline
\end{tabular}


Table 2. Criteria and indicators of the soil morphology method for floodplain restoration success assessment.

\begin{tabular}{|c|c|c|c|c|c|}
\hline Criterion & Indicators & Range & $\begin{array}{l}\text { Application } \\
\text { domain }\end{array}$ & Reference & Rationale \\
\hline \multirow{2}{*}{ Diversity } & $\begin{array}{l}\text { Simpson } \\
\text { index }\end{array}$ & $\begin{array}{l}0 \rightarrow n \text { (i.e., no } \\
\text { upper limit) }\end{array}$ & $\begin{array}{l}\text { Soil profile, } \\
\text { Topsoil }\end{array}$ & Hill (1973) & $\begin{array}{l}\text { Indicator of soil/topsoil } \\
\text { habitat diversity }(N 2) \\
\text { and evenness }(E 2)\end{array}$ \\
\hline & Richness & $0 \rightarrow n$ & $\begin{array}{l}\text { Soil profile, } \\
\text { Topsoil }\end{array}$ & & $\begin{array}{l}\text { Indicator of the number } \\
\text { of soil/topsoil habitats } \\
(N 0)\end{array}$ \\
\hline \multirow[t]{2}{*}{ Typicality } & $\begin{array}{l}\text { Frequency } \\
\text { of typical } \\
\text { soil profile } \\
\text { groups }\end{array}$ & $\begin{array}{l}\text { Expressed } \\
\text { in } \%\end{array}$ & Soil profile & AFES (2009) & $\begin{array}{l}\text { Indicator of soil typical } \\
\text { of natural floodplains }\end{array}$ \\
\hline & $\begin{array}{l}\text { Frequency } \\
\text { of typical } \\
\text { topsoil } \\
\text { groups }\end{array}$ & Idem & Topsoil & AFES (2009) & $\begin{array}{l}\text { Indicator of recent } \\
\text { changes characteristic of } \\
\text { natural floodplains }\end{array}$ \\
\hline \multirow[t]{2}{*}{ Dynamism } & $\begin{array}{l}\text { Total } \\
\text { number of } \\
\text { horizons } \\
\text { per meter } \\
\left(\mathrm{Hm}^{-1}\right)\end{array}$ & $0 \rightarrow n$ & Soil profile & $\begin{array}{l}\text { Bullinger- } \\
\text { Weber et } \\
\text { al. (2007) }\end{array}$ & $\begin{array}{l}\text { Indicator of } \\
\text { morphological changes } \\
\text { due to fluvial dynamics }\end{array}$ \\
\hline & $\begin{array}{l}\text { Elevation } \\
\text { variation } \\
\text { through } \\
\text { time }(\Delta)\end{array}$ & $-n \rightarrow n$ & Topography & & $\begin{array}{l}\text { Indicator of rate of } \\
\text { erosion/sedimentation }\end{array}$ \\
\hline
\end{tabular}

morphologies. Therefore, efficient river restoration should lead to recreating or maintaining such a high heterogeneity of soils.

Practically, we plotted the total number of horizons per meter $\left(\mathrm{Hm}^{-1}\right)$ against distance to river to get a 2-D picture of the erosion/sedimentation processes along the lateral gradient. The soil dynamism criterion was assessed by comparing the resulting patterns (1) along the river lateral gradient and (2) between the restored (open habitats + floodplain forest) and control areas.

Elevation deltas (i.e., the surface elevation variation of a given point measured through time) were calculated using cross-section topographical surveys. These surveys were done in the field using a theodolite with a precision of about $1 \mathrm{~cm}$. Negative and positive deltas are due respectively to net erosion and deposition processes. Cross-section data covering a period ranging from 1996 to 2002 (before restoration) and from 2002 to 2007 (after restoration) were used to assess elevation variations through time and flood events. Seven classes of distance to the river ( $10 \mathrm{~m}$ sections) were used to characterize the lateral gradient. Average positive and negative elevation deltas before and after the restoration and their associated standard deviations were first calculated for each distance class. Finally, two 5 yr floods (HQ5) showing similar discharges before and after the restoration were selected based on hydrological surveys of the local authorities (Canton Thurgau) and on the available cross-section data. The elevation values just before and after each of these two floods were used to characterize the erosion/sedimentation patterns for each distance class.

\subsubsection{Soil typicality criterion}

Typical floodplain soils are mainly characterized by their limited evolution and the impact of water saturation on their morphology and functioning. They all show varying frequency and duration of waterlogging. An efficient restoration should allow the complete range of typical floodplain soils to develop at a site. This potential range of soils depends on the fluvial dynamic and is therefore context specific. For example, hydromorphic features and clay-rich soils generally increase in frequency in lower river reaches. We compared the frequency of soil groups among the different areas of the site both for the entire profiles and for the topsoil horizons.

\subsection{Vegetation survey}

Vegetation surveys were conducted seven times between April 2008 and 2009 using the Braun-Blanquet (1964) method in 41 plots ( $4 \mathrm{~m}$ radius circles) distributed throughout the restored and control areas. Among these plots, 26 were 

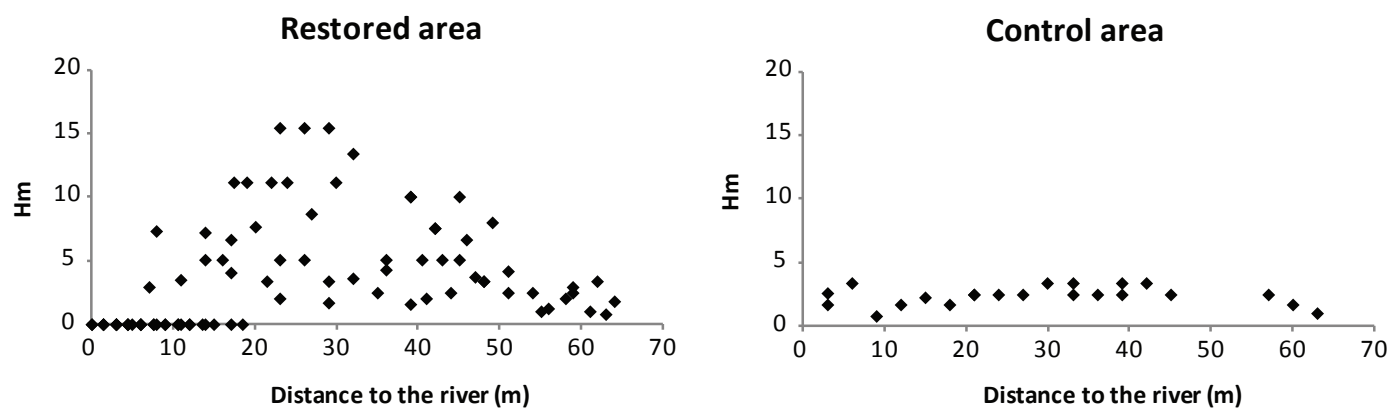

Fig. 1. Number of horizons per meter $\left(\mathrm{Hm}^{-1}\right)$ versus lateral distance to the river $(\mathrm{m})$ for the restored (left panel) and the control areas (right panel) of the River Thur site.

selected for their spatial correspondence with the soil survey, 22 in the restored area and 4 in the control. The different sampling sessions were pooled together in order to have a site-by-species matrix representing an entire year.

We calculated vascular plant species biodiversity for the three areas (open habitats + forest) using the same set of metrics as for pedodiversity. We then assessed whether the changes in soil morphology observed in Fig. 1 corresponded to vegetation types, which could be interpreted as an indication that the processes driving soil morphology and vegetation types are similar.

All calculations were done with the $\mathrm{R}$ framework (R Development core team, 2011) using package "vegan" (Oksanen et al., 2012).

\section{Results}

\subsection{Soil typology}

The cluster analysis revealed eight groups of soil profiles (average silhouette width $=0.42$ ) and seven groups of topsoils (average silhouette width $=0.44$ ). Most soil profiles could be classified as Fluvisols and to a lesser extent Regosols or Gleysols, according to the WRB classification, or FLUVIOSOL, REDOXISOL or REDUCTISOL according to the AFES classification. The average of each variable within each group is given in Table 1.

\subsection{Soil diversity}

Soil profile and topsoil diversity and richness were highest in the open habitats of the restored area and lowest in the riparian forest (Table 3). The control area had intermediate values. More soil profile and topsoil groups were present and soil profile variability was higher close to the river. Evenness of groups differed between soil profiles and topsoils. Average evenness of soil profile groups was maximal in the forest and minimal close to the river, while the evenness of topsoil groups was maximal in the un-restored pasture (control) and minimal in the forest.
Table 3. Soil profile and topsoil diversity indices calculated at the Thur site. Soil profile group richness $(N 0)$, soil profile group Simpson diversity $(N 2)$ and soil profile group evenness $(E 2)$ are given for three spatially distinct areas within the River Thur site.

\begin{tabular}{llccc}
\hline & & $N 0$ & $N 2$ & $E 2$ \\
\hline \multirow{4}{*}{ Profile } & Open habitats & 7 & 3.47 & 0.50 \\
& Forest & 2 & 1.95 & 0.97 \\
& Control area & 4 & 2.60 & 0.65 \\
\hline \multirow{4}{*}{ Topsoil } & Open habitats & 6 & 3.78 & 0.63 \\
& Forest & 4 & 2.03 & 0.51 \\
& Control area & 3 & 2.33 & 0.78 \\
\hline
\end{tabular}

\subsection{Soil dynamism}

Soil dynamism as assessed by the variation of the total number of horizons per meter $\left(\mathrm{Hm}^{1-}\right)$ along transects differed significantly between the restored and control areas (Kruskal-Wallis rank sum tests, $p=0.003$ and $p<0.001$, for $\mathrm{Hm}^{-1}$ values and standard deviation respectively) and between the open and forest habitats in the restored section. The pattern was flat in the control area (Fig. 1). Indeed, the control area was only rarely influenced by fluvial dynamics and as a result, soils were well developed and homogenous all along the lateral gradient. By contrast, in the restored area (Fig. 1), the pattern was highly variable. Five different sectors could be distinguished along the riverupland gradient. Between 0 and $5 \mathrm{~m}$ no horizon developed $\left(\mathrm{Hm}^{-1}=0\right)$. Erosion processes were dominant and soil development could not occur. Between 5 and $20 \mathrm{~m}, \mathrm{Hm}^{-1}$ values increased slightly. Sedimentation could occur with some accumulations of organic matter. Between 20 and $35 \mathrm{~m}, \mathrm{Hm}^{-1}$ values showed a high variation. Erosion, sedimentation, and soil development (i.e., accumulation of organic matter, soil layer differentiation, and in situ pedogenesis) alternated. Between 35 and $50 \mathrm{~m}, \mathrm{Hm}^{-1}$ values were more stable. Erosion decreased ad soil development increased. Further, $\mathrm{Hm}^{-1}$ values stabilized at about $2 \mathrm{Hm}^{-1}$. 
Sedimentation / Erosion before the restoration

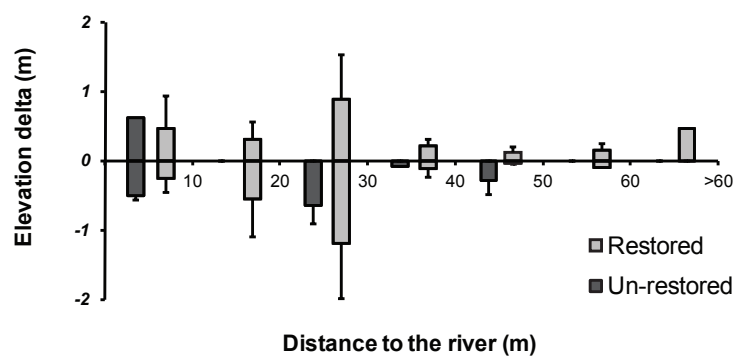

Sedimentation / Erosion after the restoration

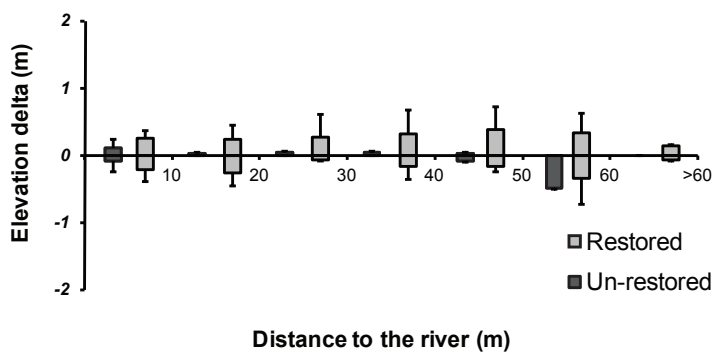

Fig. 2. Average positive and negative elevation deltas $(\mathrm{m})$ and their associated standard deviations before (left panel: period ranging from 1996 to 2002) and after the restoration (right panel: period ranging from 2002 to 2007) in the restored and in the reference (un-restored) areas of the River Thur site. Calculations are based on cross-section data for seven classes of distance to the river ( $10 \mathrm{~m}$ sections). Positive deltas $(+)$ correspond to sedimentation processes and negative deltas $(-)$ to erosion processes.

Q5 flood effect before restoration

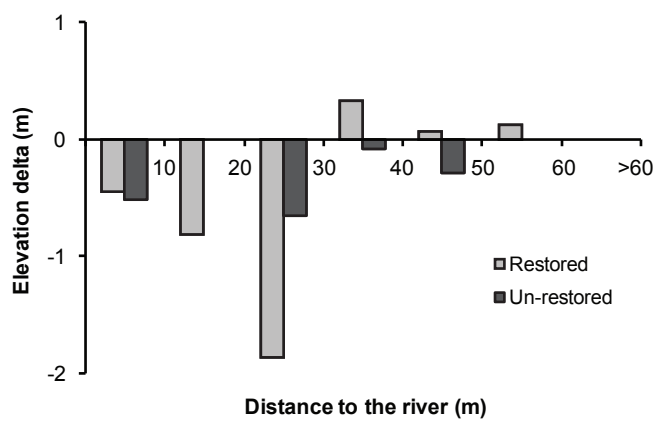

Q5 flood effect after restoration

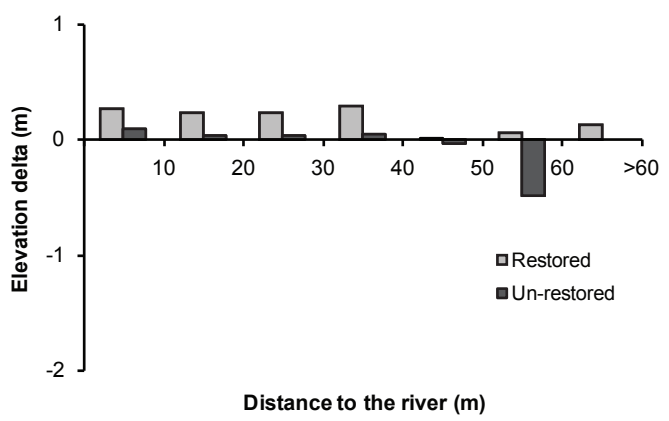

Fig. 3. Effects of a single flood with a similar discharge $(Q 5,5 \mathrm{yr}$ flood $)$ on elevation deltas $(\mathrm{m})$ in the restored and in the control area of the River Thur site before (left panel) and after restoration (right panel). Calculations are based on cross-section data for seven classes of distance to the river ( $10 \mathrm{~m}$ sections). Positive deltas $(+)$ correspond to sedimentation processes and negative deltas $(-)$ to erosion processes.

The average sedimentation and erosion rates were higher between 1996 and 2002 than for the period after restoration (Fig. 2). Indeed, the average negative elevation delta before the restoration was $-0.54 \mathrm{~m}$ and only $-0.21 \mathrm{~m}$ after. The same trend was found for the average positive delta (before $=0.22 \mathrm{~m}$ and after $=0.16 \mathrm{~m}$ ).

The effect of a similar $5 \mathrm{yr}$ flood differed significantly before and after the restoration (Fig. 3; Kruskal-Wallis rank sum test $p=0.002$ ), and between the control and restored (i.e., open habitats + forest) areas after the restoration $(p=0.02)$. Along the river's lateral gradient, the patterns were conspicuously different before and after the restoration. Before the restoration, erosion forces concentrated on the first $30 \mathrm{~m}$ from the river. Further away, erosion forces were weaker and sedimentation started to occur. After restoration, the pattern was more regular. Sedimentation processes were dominant, but erosion occurred marginally.

\subsection{Soil typicality}

Soil profile group abundances were compared among the open habitats, the riparian forest and the control for soil pro- files and topsoil layers (Table 4). In the open habitats, restoration led to the creation of thin and coarse soils (soil profile groups 4 and 5, Table 1) that correspond to the initial stages of soil development under high fluvial dynamism.

The transition between (1) the open and forest areas (soil profile groups 2 and 3) and (2) the more stable forest and control pasture (soil profile group 1) was marked by the presence of soils with low coarse material content that are less impacted by erosion and sedimentation processes, and moderately influenced by water table fluctuations. Such soils are not typical of active floodplains along natural braided rivers, but are rather an indication of human activity (i.e., embanking and associated reworking of soil and sediments). A single soil profile was characterized by the presence of a reduced horizon (soil profile group 8), indicating quasi-permanent waterlogging, a situation typically encountered along the lateral branches of braided rivers where water discharge is low.

Observed patterns in topsoil groups confirmed those of soil profile groups (Table 4): humified organic matter deeply incorporated to the soil was characteristic of the forest and pasture areas (topsoil group 1), whereas organic matter was mainly composed by coarse residues in the open restored 
Table 4. Relative abundance (\%) of soil profile and topsoil groups for the restored (Open habitats and Forest) and control areas of the River Thur site.

\begin{tabular}{lrrrrrrrr}
\hline & Group 1 & Group 2 & Group 3 & Group 4 & Group 5 & Group 6 & Group 7 & Group 8 \\
\hline Open habitats & 1.3 & 11.8 & - & 42.1 & 28.9 & 10.5 & 3.9 & 1.3 \\
Forest & - & 58.3 & - & - & - & - & 41.7 & - \\
Control area & 45.5 & 40.9 & 9.1 & - & - & 4.5 & - & - \\
\hline & & \multicolumn{7}{c}{ Soil profile } \\
\hline Open habitats & 7.9 & 27.6 & 13.2 & 39.5 & 9.2 & - & 2.6 \\
Forest & 58.3 & - & - & 8.3 & 25.0 & 8.3 & - \\
Control area & 63.6 & - & - & 22.7 & 13.6 & - & - \\
\hline
\end{tabular}

\section{Vegetation successional stages versus soil dynamism}

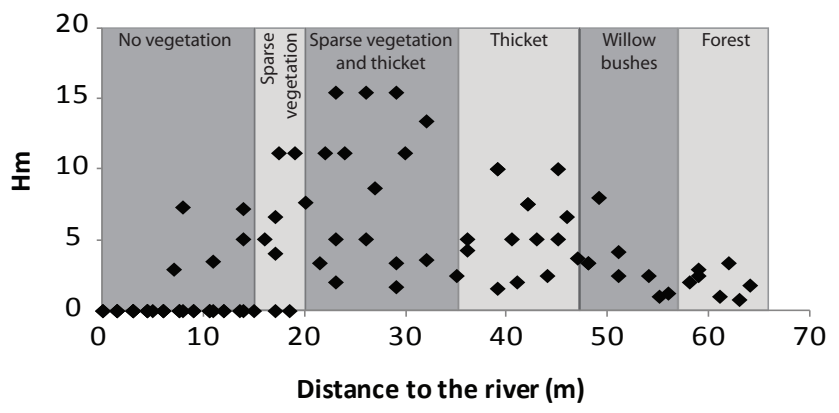

Fig. 4. Vegetation's successional stages versus soil dynamism $\left(\mathrm{Hm}^{-1}\right)$ in the restored area $(0-65 \mathrm{~m}$ from the river) of the River Thur site.

area (topsoil groups 4 and 7). Topsoils with coarse material lacking organic matter occurred close to the river (topsoil groups 2 and 3). Hydromorphic features (topsoil group 7) remained marginal as they were observed in only $3 \%$ of the investigated topsoils.

\subsection{Vegetation}

In total, 100 species were identified at the Thur River site. These species were organized into five well-differentiated vegetation stages along the lateral gradient: (1) the closest to the river, no vegetation or only isolated plants, (2) patches of pioneer vegetation and, (3) a terrestrial reed dominated by Phalaris arundinacea, (4) planted willow bushes dominated by Salix viminalis, (5) a deciduous forest dominated by Fraxinus excelsior far from the river. The control (un-restored) area was a managed pasture dominated by Arrhenatherum elatius. It was thus not meaningful to include it in the succession and compare it with the other habitats. We rather focused on the succession of plant communities along the river's lateral gradient.

Plant species diversity (N2) and evenness (E2) were higher in the forest whereas the open habitats and forest had

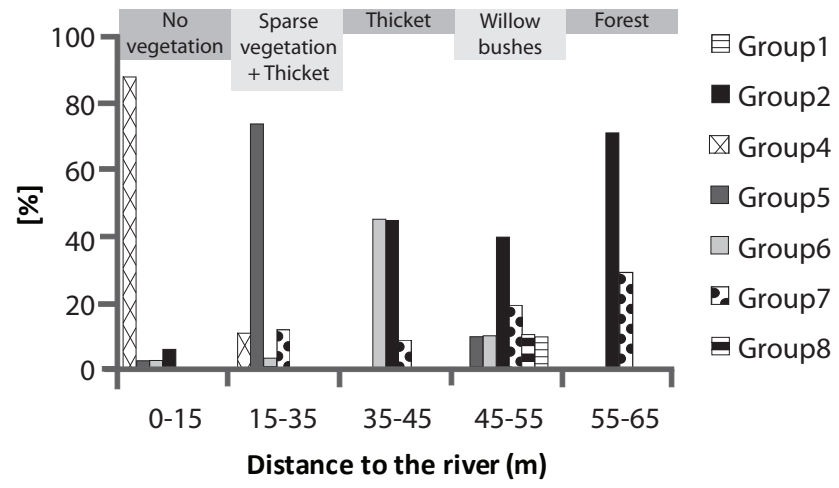

Fig. 5. Vegetation's successional stages versus frequency of soil profile groups in the restored area of the River Thur site. Soil groups are given according to their zonation along the river's lateral gradient. Soil profile group 3 was only observed in the control area.

comparable values of species richness (NO) (Table 5). The increase in plant $E 2$ paralleled the one in soil, but this was not the case for $N 0$ and $N 2$. Vegetation stages corresponded to those in soil dynamism (Fig. 4). The notable exception was the Phalaris reed vs. willow bushes where differences in vegetation did not match those observed in soil. This is most likely due to the fact that the willow bushes were planted during the restoration and are not part of the natural succession.

Vegetation was expected to respond to the composition of soil profile groups. As expected, changes in the typicality criterion reflected the broad vegetation types within the site (Fig. 5). Pioneer vegetation appeared with the first stages of soil development (soil profile group 5) whereas when soils were too poorly developed (soil profile group 4) no vegetation was present. Vegetation colonization in the most dynamic part of the gradient (soil profile group 4) was associated to organic matter accumulation (topsoil group 4). Data from topsoils, such as organic matter content and origin, are therefore complementary to those from soil profile morphology. Riparian forests (dominated by Fraxinus excelsior) mainly occurred on stable, moist soils (soil profile groups 2 
Table 5. Averages of plant species biodiversity metrics for the open and forest habitats of the River Thur site.

\begin{tabular}{lccc}
\hline & $N 0$ & $N 2$ & $E 2$ \\
\hline Open habitats & 17.88 & 2.87 & 0.17 \\
Forest & 16.71 & 4.88 & 0.30 \\
\hline
\end{tabular}

and 7). Potential surfaces of suitable hydromorphic soils for the typical vegetation of braided, lateral river branches such as Typha minima and Inula helvetica, for which reintroduction plans exist in Switzerland (Keel and Flöss, 2004; Flöss and Keel, 2004), were only limited in our study area (i.e., only one sampling point for profile group 8).

\section{Discussion}

The restoration of the River Thur increased soil diversity, and improved soil dynamism and typicality at the site. It changed the fluvial dynamics leading to changes in soil morphology (e.g., intensity of erosion/sedimentation processes; coarse material and organic matter content) and soil functioning (e.g., loss of hydromorphy). The most striking changes occurred within the first $30 \mathrm{~m}$ from the river where postrestoration fluvial dynamics created diverse and dynamic patterns of soils. Habitats located further away from the river were less frequently exposed to floods and therefore less influenced by the restored fluvial dynamic.

Given the known importance of soils in determining vascular plant communities (Gobat, 2010), we hypothesized that investigating the correlations between soil profile and topsoil groups and vascular plant communities would provide information on the ongoing ecological processes of a restored site. These correlations were weak for diversity and richness most likely due to the influence of factors such as soil chemistry, water and nutrient availability, surface, connectivity, biotic interactions and species reservoir. However, changes in the evenness of soil profile groups, and in soil dynamism and typicality paralleled those observed for vegetation suggesting that similar ecological processes are driving soils and plant communities. Indeed, the $\mathrm{Hm}^{-1}$ index reflected the vegetation's successional stages. Such associations were already demonstrated between soil texture and moisture and Salix nigra (Schaff et al., 2003). These results agree with the idea that restoring the physical heterogeneity of a site promotes its biological diversity (Miller et al., 2010; Palmer et al., 2010) and gives a positive signal for project evaluation. However, the extent to which weak or strong correlations will improve or hamper a restoration project's success remains to be determined.

River restoration by widening had not yet succeeded in creating significant surfaces of hydromorphic soils typical of braided, lateral river branches (AFES, 2009; Guenat et al., 2003; IUSS Working Group, 2006) and influencing both fauna and flora (Godreau et al., 1999). Given that the formation of such soils in natural floodplains can take considerable time, the creation of artificial landscapes where hydromorphic soils could persist may provide more immediate results if restoration objectives require so. Examples of restoration projects that used artificial landscapes to achieve their aims exist. In the framework of the "Project River Recovery" aiming at restoring riverine and wetland habitats in New Zealand, Caruso (2006) concludes that wetland construction and enhancement can maintain and increase usable habitat and native bird populations. MacWilliams Jr. et al. (2010) show that through the construction of a compound channel, the incision of the main channel was stopped and a significant increase in floodplain vegetation relative to the prior condition was observed. Willows and other types of vegetation have established on the floodplain and within the constructed low-flow channel, and evidence of wildlife utilization of the riparian zone is abundant.

However, hydromorphic soils may also be created naturally following major floods (i.e., HQ20, HQ50 or HQ100) that did not occur between the restoration and the present study (Table S1 in the Supplement). Indeed, only HQ5 and HQ10 floods resulting in weak sedimentation and/or erosion processes in forest sites occurred during this time period. As a result, it is difficult to conclude whether the restoration succeeded in improving hydromorphic processes.

Nevertheless, $5 \mathrm{yr}$ after restoration, the increased diversity of soil types and the dramatic changes of dynamism suggest a positive impact of restoration, despite the potential for further improvement suggested by the lack of typical hydromorphic soils. Thus, $5 \mathrm{yr}$ after river widening, soil morphology indicators suggest that this restoration project was a partial success in restoring soil habitat and vegetation. The follow-up assessment after several major floods ( $\geq$ HQ20) should take place to allow for testing of the longer-term validity of our conclusion for the River Thur site.

Previous evaluations of the same Thur River site based on different methods, criteria and indicators, reached similar conclusions. Woolsey et al. (2007) found that fish assemblage structure and composition were similar in embanked and restored reaches and concluded that the restoration of the River Thur failed to meet the objectives of near-natural abundance and diversity of fauna. Weber et al. (2009) showed that hydrophysical habitat diversity had been improved by the widening but that the current geomorphological complexity was still considerably impaired at the restored reach in comparison with historical near-natural shoreline. Rohde (2004) used GIS methods based on landscape indexes and vegetation and concluded that the widening improved the degree of vegetation naturalness but in a limited way as compared to other restoration projects. Although the methods used in our study were fundamentally different, the results obtained using soil morphology were in agreement with these other evaluations. Moreover, the indicators we used also allowed investigating complementary aspects of floodplain restoration: 
the diversity criterion proved to be complementary to vegetation surveys, the dynamism criterion discriminated precisely the zones that were differently impacted by the fluvial dynamic and the typicality criterion allowed characterizing the changes among these zones.

In the context of river restoration, indicators should be easily measured, be sensitive to stresses on the system, demonstrate predictable responses to stresses and be integrative (Palmer et al., 2005). Our results show that soil morphology criteria and indicators fit these requirements. Soils may respond slowly to perturbations such as riverbed widening, however, in our case, clear changes in soil morphology were already observed $5 \mathrm{yr}$ after restoration even though no major floods had taken place in the time elapsed since restoration. Furthermore, soil indicators provide two different and complementary levels of information (i.e., soil profiles and topsoils). Nevertheless, the time between the restoration and the integration of the changes into soil morphology depends on the fluvial regime. Successive floods (including HQ5, HQ10, or HQ20) have to occur to potentially modify the soil morphology. Erosional and depositional processes should be frequent, ideally corresponding to the "mediumenergy non cohesive floodplains" river category of Nanson and Croke (1992) with braided, meandering and anastomosing channels. Here, we studied the relatively short-term effects of floodplain restoration. According to Ballantine and Schneider (2009), as soil development is a relatively slow process, which only appears to accelerate later in the successional recovery sequence, the role of different soil successional phases in determining long-term trajectories of ecosystem development should be considered in restoration design, research, and monitoring. It would therefore be useful to assess the longer-term trends of soil development at the study site and other comparable restored floodplains to test the broader applicability of the soil morphology approach.

\section{Conclusions}

Our results show that soil morphology responded fast and clearly to river restoration and that typicality and dynamism correlated to vegetation changes. Analysis of soil morphology has thus the potential to improve the quality and accuracy of rapid assessment protocols (Sifneos et al., 2010; Stein et al., 2009).

Despite the known importance of soils in terrestrial ecology, soil morphology has been underused for the assessment of floodplain restoration success. The number of river restoration projects is increasing rapidly but there is still no general agreement on evaluation methods. The analysis of soil morphology offers many advantages (ease of use, quick and cost-effective) that make it a promising approach for the river restoration evaluator's tool kit.

\section{Supplementary material related to this article is available online at http://www.hydrol-earth-syst-sci.net/ 17/4031/2013/hess-17-4031-2013-supplement.pdf.}

Acknowledgements. The authors kindly acknowledge the ETHDomain Competence Center Environment and Sustainability (CCES) project RECORD, the EPFL and the University of Neuchâtel for funding, Karin Grin for fieldwork and Ralph Thielen for helping in the data collection.

Edited by: B. McGlynn

\section{References}

AFES: Référentiel pédologique 2009, Collection Savoir-Faire, Editions Quae, Versailles, Paris, 2009.

Baer, O.: Géographie de la Suisse, Editions Delta, Vevey, 1976.

Ballantine, K. and Schneider, R.: Fifty-five years of soil development in restored freshwater depressional wetlands, Ecol. Appl., 19, 1467-1480, doi:10.1890/07-0588.1, 2009.

Bernhardt, E. S., Palmer, M. A., Allan, J. D., Alexander, G., Barnas, K., Brooks, S., Carr, J., Clayton, S., Dahm, C., Follstad-Shah, J., Galat, D., Gloss, S., Goodwin, P., Hart, D., Hassett, B., Jenkinson, R., Katz, S., Kondolf, G. M., Lake, P. S., Lave, R., Meyer, J. L., O'Donnell, T. K., Pagano, L., Powell, B., and Sudduth, E.: Ecology: Synthesizing U.S. river restoration efforts, Science, 308, 636-637, doi:10.1126/science.1109769, 2005.

Bernhardt, E. S., Sudduth, E. B., Palmer, M. A., Allan, J. D., Meyer, J. L., Alexander, G., Follastad-Shah, J., Hassett, B., Jenkinson, R., Lave, R., Rumps, J., and Pagano, L.: Restoring rivers one reach at a time: Results from a survey of U.S. river restoration practitioners, Restor. Ecol., 15, 482-493, 2007.

Braun-Blanquet, J.: Pflanzensoziologie, Grundzüge der Vegetationskunde, Springer, Wien, 1964.

Bullinger-Weber, G. and Gobat, J. M.: Identification of facies models in alluvial soil formation: The case of a Swiss alpine floodplain, Geomorphology, 74, 181-195, doi:10.1016/j.geomorph.2005.07.016, 2006.

Bullinger-Weber, G., Le Bayon, R.-C., Guenat, R.-C., and Gobat, J.M.: Influence of some physicochemical and biological parameters on soil structure formation in alluvial soils, Eur. J. Soil Biol., 43, 57-70, 2007.

Bush, J. K.: Soil nitrogen and carbon after twenty years of riparian forest development, Soil Sci. Soc. Am. J., 72, 815-822, doi:10.2136/sssaj2007.0120, 2008.

Caruso, B. S.: Project River Recovery: restoration of braided gravelbed river habitat in New Zealand high country, Environ. Manage., 37, 840-861, 2006.

Caylor, K. K., Manfreda, S., and Rodriguez-Iturbe, I.: On the coupled geomorphological and ecohydrological organization of river basins, Adv. Water Resour., 28, 69-86, doi:10.1016/j.advwatres.2004.08.013, 2005.

Cole, C. and Kentula, M.: Monitoring and assessment-What to measure ... and why, in: Wetlands, edited by: LePage, B. A., Springer, the Netherlands, 137-152, 2011. 
Daniels, J. M.: Floodplain aggradation and pedogenesis in a semiarid environment, Geomorphology, 56, 225-242, doi:10.1016/S0169-555X(03)00153-3, 2003.

Diem, S., Renard, P., Schirmer, M.: New methods to estimate 2D water level distributions of dynamic rivers, Ground Water, doi:10.1111/gwat.1, online first, 2012.

Everitt, B., Landau, S., and Leese, M.: Cluster analysis, Hodder Arnold, London, 237 pp., 2001.

Flöss, I. and Keel, A.: Aktionsplan Kleiner Rohrkolben (Typha minima Hoppe), Artenschutzmassnahmen für gefährdete Farn- und Blütenpflanzen im Kanton Zürich, Fachstelle Naturschutz Kanton Zürich, Zürich, 2004.

Gallandat, J. D., Gobat, J.-M., and Roulier, C.: Cartographie des zones alluviales d'importance nationale: rapport et annexes, in: Cahiers de l'environnement, No. 199, Office fédéral de l'environnement, des forêts et du paysage (OFEFP), Berne, 1993.

Gerrard, A. J.: Soil Geomorphology: An Integration of Pedology and Geomorphology, Chapman \& Hall, 260 pp., London, 1992.

Gobat, J. M.: The living soil: fundamentals of soil science and soil biology, Science Publishers, Enfield, 2010.

Godreau, V., Bornette, G., Frochot, B., Amoros, C., Castella, E., Oertli, B., Chambaud, F., Oberti, D., and Craney, E.: Biodiversity in the floodplain of Saône: a global approach, Biodivers. Conserv., 8, 839-864, doi:10.1023/a:1008807328566, 1999.

Guenat, C., Bureau, F., and Charnet, F.: Genèse, diversité et fonctionnement des sols sous la dépendance d'un cours d'eau: écologie, fonctions et gestion, in: Forêts riveraines des cours d'eau, IDF, Paris, 2003.

Heneghan, L., Miller, S. P., Baer, S., Callaham, M. A., Montgomery, J., Pavao-Zuckerman, M., Rhoades, C. C., and Richardson, S.: Integrating soil ecological knowledge into restoration management, Restor. Ecol., 16, 608-617, doi:10.1111/j.1526100X.2008.00477.x, 2008.

Hill, M. O.: Diversity and Evenness: A Unifying Notation and Its Consequences, Ecology, 54, 427-432, doi:10.2307/1934352, 1973.

Ibánez, J. J., De-Albs, S., Bermúdez, F. F., and García-Álvarez, A.: Pedodiversity: concepts and measures, Catena, 24, 215-232, doi:10.1016/0341-8162(95)00028-Q, 1995.

Ibáñez, J. J., De-Alba, S., Lobo, A., and Zucarello, V.: Pedodiversity and global soil patterns at coarse scales, Geoderma, 83, 171-192, doi:10.1016/S0016-7061(97)00147-X, 1998.

Imboden, C.: Eaux vivantes, edited by: LSPN, Département fédéral de l'Intérieur, Bâle, 1976.

IUSS Working Group: World Reference Base for Soil Resources, in: World Soil Resources Report 103, Food and Agriculture Organization of the United Nations, Rome, 128 pp., 2006.

Keel, A. and Flöss, I.: Aktionsplan Schweizer Alant (Inula helvetica Weber), Artenschutzmassnahmen für gefährdete Farn- und Blütenpflanzen im Kanton Zürich, Fachstelle Naturschutz Kanton Zürich, Zürich, 2004

MacWilliams Jr., M., Tompkins, M., Street, R., Kondolf, G., and Kitanidis, P.: Assessment of the effectiveness of a constructed compound channel river restoration project on an incised stream, J. Hydraul. Eng.-ASCE, 136, 1042-1052, 2009.

Malmqvist, B. and Rundle, S.: Threats to the running water ecosystems of the world, Environ. Conserv., 29, 134-153, doi:10.1017/S0376892902000097, 2002.
Miller, S. W., Budy, P., and Schmidt, J. C.: Quantifying Macroinvertebrate Responses to In-stream habitat restoration: Applications of meta-analysis to river restoration, Restor. Ecol., 18, 8 19,2010

Moor, M.: Pflanzengesellschaften schweizerischer Flussauen, Mit Sch. Anst. Forstl. Versuchsw., 34, 221-360, 1958.

Naiman, R., Bechtold, J., Drake, D., Latterell, J., O'Keefe, T., and Balian, E.: Origins, patterns, and importance of heterogeneity in riparian systems, in: Ecosystem function in heterogeneous landscapes, Springer-Verlag, New York, 279-309, 2005.

Nakamura, K., Amano, K., and Tockner, K.: River restoration: European perspectives and lessons for Japan, Ecol. Civ. Eng., 8, 201-214, 2006.

Nakamura, K., Tockner, K., and Amano, K.: River and wetland restoration: Lessons from Japan, Bioscience, 56, 419-429, doi:10.1641/0006-3568(2006)056[0419:rawrlf]2.0.co;2, 2009.

Nanson, G. C. and Croke, J. C.: A genetic classification of floodplains, Geomorphology, 4, 459-486, doi:10.1016/0169555X(92)90039-Q, 1992.

Nassauer, J. I., Kosek, S. E., and Corry, R. C.: Meeting public expectations with ecological inovation in riparian landscapes, J. Am. Water Resour. Assoc., 37, 1439-1443, doi:10.1111/j.17521688.2001.tb03650.x, 2001.

Oksanen, J., Blanchet, F. G., Kindt, R., Legendre, P., Minchin, P. R., O'Hara, R. B., Simpson, G. L., Solymos, P., Stevens, M. H. H., and Wagner, H.: vegan: Community Ecology Package, available at: http://CRAN.R-project.org/package=vegan, 2012.

Orr, C. H., Stanley, E. H., Wilson, K. A., and Finlay, J. C.: Effects of restoration and reflooding on soil denitrification in a leveed midwestern floodplain, Ecol. Appl., 17, 2365-2376, doi:10.1890/062113.1, 2007.

Palmer, M. A. and Bernhardt, E. S.: Hydroecology and river restoration: Ripe for research and synthesis, Water Resour. Res., 42, W03S07, doi:10.1029/2005WR004354, 2006.

Palmer, M. A., Bernhardt, E. S., Allan, J. D., Lake, P. S., Alexander, G., Brooks, S., Carr, J., Clayton, S., Dahm, C. N., Shah, J. F., Galat, D. L., Loss, S. G., Goodwin, P., Hart, D. D., Hassett, B., Jenkinson, R., Kondolf, G. M., Lave, R., Meyer, J. L., O’Donnell, T. K., Pagano, L., and Sudduth, E.: Standards for ecologically successful river restoration, J. App. Ecol., 42, 208-217, 2005.

Palmer, M. A., Allan, J. D., Meyer, J., and Bernhardt, E. S.: River restoration in the twenty-first century: data and experiential knowledge to inform future efforts, Restor. Ecol., 15, 472-481, 2007.

Palmer, M. A., Menninger, H. L., and Bernhardt, E. S.: River restoration, habitat heterogeneity and biodiversity: a failure of theory or practice?, Freshwater Biol., 55, 205-222, 2010.

Quideau, S. A., Chadwick, O. A., Benesi, A., Graham, R. C., and Anderson, M. A.: A direct link between forest vegetation type and soil organic matter composition, Geoderma, 104, 41-60, doi:10.1016/S0016-7061(01)00055-6, 2001.

R Development Core Team: R: A language and environment for statistical computing, $\mathrm{R}$ foundation for statistical computing, Vienna, Austria, 2011.

Rohde, S.: River Restoration: Potential and limitations to reestablish riparian landscapes, Assessment \& Planning, PhD thesis, Swiss Federal Institute of Technology Zurich, Zurich, 133 pp., 2004 
Rohde, S., Kienast, F., and Bürgi, M.: Assessing the Restoration Success of River Widenings: A Landscape Approach, Environ. Manage., 34, 574-589, 2004.

Roulier, C.: Typologie et dynamique de la végétation des zones alluviales de Suisse, Geobotanica Helvetica, 72, 138 pp., 1998.

Rousseeuw, P.: Silhouettes: a graphical aid to the interpretation and validation of cluster analysis, J. Comput. Appl. Math., 20, 53-65, 1987.

Saldaña, A. and Ibáñez, J. J.: Pedodiversity analysis at large scales: an example of three fluvial terraces of the Henares River (central Spain), Geomorphology, 62, 123-138, doi:10.1016/j.geomorph.2004.02.007, 2004.

Saldaña, A. and Ibáñez, J. J.: Pedodiversity, connectance and spatial variability of soil properties, what is the relationship?, Ecol. Model., 208, 342-352, doi:10.1016/j.ecolmodel.2007.06.006, 2007.

Saxton, K. E., Rawls, W. J., Romberger, J. S., and Papendick, R. I.: Estimating generalized soil-water characteristics from texture, Soil Sci. Soc. Am. J., 50, 1031-1036, 1986.

Schaff, S. D., Pezeshki, S. R., and Shields Jr., F. D.: Effects of soil conditions on survival and growth of black willow cuttings, Environ. Manage., 31, 748-763, 2003.

Schirmer, M.: Das RECORD-Projekt - Flussrevitalisierung, eine ökologische Massnahme in einem komplexen Umfeld, Aqua Gas, 3, 22-28, 2013.

Schneider, P., Vogt, T., Schirmer, M., Doetsch, J., Linde, N., Pasquale, N., Perona, P., and Cirpka, O. A.: Towards improved instrumentation for assessing river-groundwater interactions in a restored river corridor, Hydrol. Earth Syst. Sci., 15, 2531-2549, doi:10.5194/hess-15-2531-2011, 2011.

Sifneos, J., Herlihy, A., Jacobs, A., and Kentula, M.: Calibration of the Delaware Rapid Assessment Protocol to a comprehensive measure of wetland condition, Wetlands, 30, 1011-1022, doi:10.1007/s13157-010-0093-z, 2010.
Stein, E. D., Fetscher, A. E., Clark, R. P., Wiskind, A., Grenier, J. L., Sutula, M., Collins, J. N., and Grosso, C.: Validation of a wetland rapid assessment method: use of Epa's Level 1-2-3 framework for method testing and refinement, Wetlands, 29, 648-665, doi:10.1672/07-239.1, 2009.

Sudduth, E. B., Meyer, J. L., and Bernhardt, E. S.: Stream restoration practices in the southeastern United States, Restor. Ecol., 15, 573-583, 2007.

Sutton-Grier, A. E., Kenney, M. A., and Richardson, C. J.: Examining the relationship between ecosystem structure and function using structural equation modelling: A case study examining denitrification potential in restored wetland soils, Ecol. Model., 221, 761-768, doi:10.1016/j.ecolmodel.2009.11.015, 2010.

Tockner, K. and Stanford, J. A.: Riverine flood plains: present state and future trends, Environ. Conserv., 29, 308-330, 2002.

Toomanian, N. and Esfandiarpoor, I.: Challenges of pedodiversity in soil science, Eurasian Soil Sci., 43, 1486-1502, doi:10.1134/s1064229310130089, 2010.

Wardle, D. A.: Communities and ecosystems: linking the aboveground and belowground components, Princeton University Press, Princeton, New Jersey, 2002.

Weber, C., Schager, E., and Peter, A.: Habitat diversity and fish assemblage structure in local river widenings: A case study on a swiss river, River Res. Appl., 25, 687-701, doi:10.1002/rra.1176, 2009.

Wohl, E., Angermeier, P. L., Bledsoe, B., Kondolf, G. M., MacDonnell, L., Merritt, D. M., Palmer, M. A., Poff, N. L., and Tarboton, D.: River restoration, Water Resour. Res., 41, 1-12, 2005.

Woolsey, S., Capelli, F., Gonser, T., Hoehn, E., Hostmann, M., Junker, B., Paetzold, A., Roulier, C., Schweizer, S., Tiegs, S. D., Tockner, K., Weber, C., and Peter, A.: A strategy to assess river restoration success, Freshwater Biol., 52, 752-769, 2007. 